\title{
Microzooplankton: major herbivores in an estuarine planktonic food web
}

\author{
J. N. Putland ${ }^{1,2, *}$, R. L. Iverson ${ }^{1}$ \\ ${ }^{1}$ Department of Oceanography, Florida State University, Tallahassee, Florida 32306-4320, USA \\ ${ }^{2}$ Present address: Harbor Branch Oceanographic Institution, 5600 Highway U.S. 1 North, Ford Pierce, Florida 34946, USA
}

\begin{abstract}
Microzooplankton, on average, ingested 10 times more phytoplankton productivity than Acartia tonsa, which dominates the mesozooplankton community in Apalachicola Bay, Florida, USA. Microzooplankton ingested $<75$ and $>75 \%$ of phytoplankton productivity during winter and summer, respectively. Ciliates, particularly ciliates $<20 \mu \mathrm{m}$ in size, were abundant in all samples. Phytoplankton was the main ( $>50 \%$ ) component of the microzooplankton diet during the summer high productivity period. Because microzooplankton are prey for organisms occupying higher trophic levels, such as copepods, fish larvae, and oysters, we propose that energy and mass flows mainly from phytoplankton through microzooplankton to higher trophic levels in Apalachicola Bay. A reduction in discharge from the Apalachicola River during our study period led to reductions in rates of grazing, ingestion, and productivity of microzooplankton at a particular salinity. Reduced river discharge also increased the areal extent of higher salinity water where ingestion and productivity of microzooplankton were relatively low. Because microzooplankton are key constituents of the estuarine food web in Apalachicola Bay, upstream water diversion that increases the areal extent of higher salinity water in the bay, can be expected to lower microzooplankton productivity and therefore reduce higher trophic level productivity in the bay.
\end{abstract}

KEY WORDS: River flow $\cdot$ Management $\cdot$ Estuarine $\cdot$ Food web structure $\cdot$ Microzooplankton

\section{INTRODUCTION}

Apalachicola Bay is a highly productive estuary located in the northern Gulf of Mexico. The bay serves as a habitat and nursery to a wide variety of commercial and sport fish species such as oyster, sheepshead, seatrout, herring, shrimp, and blue crab (Livingston 1984). The high productivity is the result of the Apalachicola River delivering freshwater and nutrients to the bay (Mortazavi 1998). Freshwater moderates salinity in the bay, which creates a suitable habitat for estuarine flora and fauna. Nutrients delivered to the bay support high levels of phytoplankton productivity (Mortazavi 1998) that, in turn, supports secondary productivity (Chanton \& Lewis 2002). Diversion of water upstream of the Apalachicola River has been proposed for the summer in order to satisfy domestic and agricultural needs. Previous work observed that reduced river discharge increases the areal extent of higher salinity water in the bay (Mortazavi 1998) and leads to reduced productivity of higher trophic levels (Livingston et al. 1997). Determining the ecology of key constituents of the estuarine food web, such as zooplankton, in the Bay will help identify mechanisms by which upstream water diversion can lead to reduced productivity of higher trophic levels.

The classical diatom-copepod-fish food chain describes the transfer of phytoplankton productivity to higher trophic levels in productive marine waters (Riegman et al. 1993, Legendre \& Rassoulzadegan 1995). In Apalachicola Bay, nutrient concentrations are relatively high (Mortazavi 1998), and calculations suggest that zooplankton grazing is the primary loss process controlling phytoplankton productivity and biomass in the bay (Mortazavi 1998), and diatoms (Estabrook 1973) and copepods (Edmiston 1979) are abundant. Therefore, a classical diatom-copepod-fish food chain might describe planktonic food web struc- 
ture in Apalachicola Bay. However, microzooplankton are abundant in estuarine waters (Gifford \& Caron 2000). Furthermore, recent studies indicate that microzooplankton are generally the primary herbivores in oceanic, coastal, and estuarine waters (Calbet \& Landry 2004). Microzooplankton are also prey to higher trophic levels such as copepods (Rollwagen Bollens \& Penry 2003), oysters (Dupuy et al. 1999), larval shellfish (Nagano \& Decamp 2004) and larval fishes (Fukami et al. 1999) that inhabit estuaries. Therefore, the classical diatom-copepodfish food chain, where copepods are the main secondary producers, may not be an accurate representation of mass and energy flow through the planktonic food web in Apalachicola Bay or other estuaries.

The first objective of the present study was to test the hypothesis that microzooplankton are the primary herbivores in Apalachicola Bay. If microzooplankton are the main herbivores, then the percent of phytoplankton productivity ingested by microzooplankton will be greater than that ingested by mesozooplankton. Data obtained from a parallel study of mesozooplankton grazing were used to test this hypothesis (Putland \& Iverson 2007). The second objective of this study was to examine relationships between microzooplankton parameters and salinity in the bay, specifically during summer when river diversion has been proposed. We chose to examine parameters with respect to salinity as opposed to station locations, because salinity and nutrient concentrations at specific stations are highly variable because of daily variations in river flow, wind speed, and tides. Moreover, because reduced river discharge decreases the areal extent of lower salinity water in the bay, we wanted to know the relationship between microzooplankton parameters and salinity to help understand the mechanisms by which reduced river discharge can lead to reduced productivity of higher trophic levels. It was beyond the scope of this study to determine if salinity per se influences the biological parameters examined. To accomplish these objectives, we examined microzooplankton bacterivory and herbivory within various salinity regimes in Apalachicola Bay throughout a 2 yr period (2003 through 2004).

\section{MATERIALS AND METHODS}

Physical environment. The physical attributes of Apalachicola Bay (Fig. 1) were described by Livingston (1984). The bay is an estuary that represents the largest area of the Apalachicola Bay system. The bay is

bound by barrier islands (St. Vincent, St. George, and Dog Island) to the south and west and separated from St. George Sound by a submerged shoal. Exchange between bay and gulf water occurs through St. George Sound and openings (East Pass, Sikes Cut, West Pass, Indian Pass) through the barrier islands. Water moves predominantly from the east into St. George Sound and out to the gulf through West Pass. Residence time of water ranges from 2 to 12 d (Mortazavi 1998). Average depth of the bay is between 2 and $3 \mathrm{~m}$ and, as a result of wind and tides, which are diurnal to semidiurnal with about 0.1 to $0.2 \mathrm{~m}$ range, the bay is generally well mixed. However, freshwater derived from the local rainfall and the Apalachicola River can lead to instances of bay water column stratification. The Apalachicola River is, in terms of discharge, the largest in Florida and the main source of freshwater to the bay. Headwaters of the Apalachicola River are formed at Lake Seminole where waters from the Flint and Chattahoochee Rivers meet. River flow typically peaks during spring and is minimal during summer. Annual average flow is about $665 \mathrm{~m}^{3} \mathrm{~s}^{-1}$. River flow is closely related to precipitation in Georgia and is considered the main determinant of salinity structure in the estuary.

Sampling. Samples were, in general, collected monthly from Apalachicola Bay throughout 2003 and 2004. We did not sample from fixed station locations. Instead, on each collection date, water was sampled from oligo-, meso-, and polyhaline portions of the bay. Water samples were not collected at any specific time of the day or tidal cycle; they were collected from surface to $0.5 \mathrm{~m}$ depth below sea surface with a darkened 
carboy. Immediately after collection, water was subsampled from the carboy for phytoplankton, bacterioplankton, and protist analyses. The remainder of the water collected was used for microzooplankton grazing experiments. Temperature and salinity were measured at $0.5 \mathrm{~m}$ depth intervals throughout the water column with a $\mathrm{YSI}^{\odot}$ salinometer.

Chlorophyll $a$ and bacterial abundance. Seawater for chlorophyll a analysis was stored on ice in polyethylene bottles for $<4 \mathrm{~h}$ prior to being filtered through $47 \mathrm{~mm} \mathrm{GF/F}$ filters at $<117 \mathrm{~mm} \mathrm{Hg}$ vacuum. Filtered samples were stored in darkness at $-20^{\circ} \mathrm{C}$ and analyzed within $1 \mathrm{wk}$ of sample collection. Chlorophyll $a$ was extracted from filters in $90 \%$ acetone for about $24 \mathrm{~h}$ at $-20^{\circ} \mathrm{C}$. The concentration of chlorophyll a was measured fluorometrically with a Model 10 Turner Designs $^{\odot}$ fluorometer equipped with filter sets for optimal sensitivity of chlorophyll $a$ in the presence of chlorophyll $b$ and phaeopigments (Welschmeyer 1994).

Seawater samples for bacterioplankton analyses were preserved with glutaraldehyde ( $2 \%$ final concentration) and stored in darkness at $4{ }^{\circ} \mathrm{C}$. Bacteria were enumerated within $2 \mathrm{wk}$ of sample collection. Samples were filtered (<117 mm Hg vacuum) onto $0.2 \mu \mathrm{m}$ black Poretics polycarbonate filters and stained with Acridine Orange (Hobbie et al. 1977). Filters were mounted with Cargille Type B immersion oil onto glass slides. A $\mathrm{BH}$ Olympus ${ }^{\odot}$ epifluorescence microscope equipped with a blue excitation filter set (U-MWIB, excitation 460 to $490 \mathrm{~nm}$; emission 515 to $700 \mathrm{~nm}$ ) was used to visualize bacteria. Cells were counted at a total magnification of $\times 1875$. At least 100 cells (Hobro \& Willen 1977) were counted per sample in a minimum of 10 random fields.

Microzooplankton abundance. Samples for the analysis of heterotrophic flagellates 5 to $20 \mu \mathrm{m}$ in size were preserved in glutaraldehyde ( $2 \%$ final concentration) and stored in darkness at $4^{\circ} \mathrm{C}$ (Gifford \& Caron 2000). Flagellates were enumerated within 1 mo of sample collection. Samples were filtered $(<117 \mathrm{~mm} \mathrm{Hg}$ vacuum) onto $5 \mu \mathrm{m}$ Poretics polycarbonate filters and stained with Acridine Orange (1\% final concentration) (Sherr et al. 1993). Filters were mounted with Cargille Type B immersion oil onto glass slides. A BH Olympus ${ }^{\odot}$ epifluorescence microscope equipped with a blue/UV excitation filter set (U-M546, excitation 400 to $410 \mathrm{~nm}$; emission 455 to $700 \mathrm{~nm}$ ) was used to visualize cells. Cells that lacked red autofluorescence, indicative of chlorophyll $a$, were counted at a total magnification of $\times 1875$. For each filter, at least 100 cells were counted in either transects or in a minimum of 10 random fields.

Samples for the analysis of ciliates, flagellates $>20 \mu \mathrm{m}$, and dinoflagellates $>20 \mu \mathrm{m}$ were preserved in acid Lugol's solution ( $2 \%$ final concentration) and stored in darkness at $4^{\circ} \mathrm{C}$ (Gifford \& Caron 2000). Sam- ples were enumerated within 1 mo of sample collection. Samples (10 to $50 \mathrm{ml}$ ) were settled for $24 \mathrm{~h}$ in Utermöhl settling chambers. Cells were counted through phase-contrast light microscopy at a total magnification of $\times 200$ with an inverted Wild ${ }^{\odot}$ microscope. For each settled sample, transects were counted until at least 100 cells had been counted.

Microzooplankton grazing measurements. The dilution technique (Landry \& Hassett 1982) was used to estimate microzooplankton herbivory and bacterivory. Prior to conducting microzooplankton grazing studies, all equipment that would contact seawater was soaked for a few days in 10\% hydrochloric acid. Afterward, equipment was thoroughly rinsed and then soaked for several days in Nanopure water. Nitrile gloves were worn during all water handling procedures.

Seawater for the size-fractionated $(<202 \mu \mathrm{m})$ predator and prey populations was collected with a darkened polycarbonate carboy from a depth of about $0.5 \mathrm{~m}$ below sea surface. Water for preparing the particlefree diluent was collected from the seawater intake system at the Florida State University Edward Ball Marine Laboratory. Salinity near the marine laboratory is typically greater than about 28 psu. We collected freshwater from the river and combined it with seawater collected from the intake system to match the salinity of the particle-free water with that of the seawater collected for the size-fractionated predator and prey populations.

Silicate does not limit phytoplankton growth in Apalachicola Bay. While phosphorus tends to limit phytoplankton productivity in lower salinity waters (<20 psu), wind mixing alleviates phosphorus limitation (Fulmer 1997). Only nitrogen (as ammonium chloride) was added to the incubation bottles because it is the nutrient that most frequently limits phytoplankton productivity in this estuary (Fulmer 1997). Inorganic nitrogen was added to all incubation bottles to ensure that prey growth did not become nitrogen limited during the course of the incubations. Enough ammonium chloride was added to bottles to elevate nitrogen concentrations in bottles to those found in the river. Since nutrient analyses were not synchronous with sampling, we determined the enrichment based on the difference between nitrogen concentrations in the river and that at a station with similar salinity for the previous month. One bottle per dilution assay $(0 \%$ dilution factor) served as a control.

To reduce preparation time of diluent, seawater was serially gravity-filtered through 25 and $5 \mu \mathrm{m}$ Sears drinking quality grade filters. The $<5 \mu \mathrm{m}$ filtrate was then filtered through $0.2 \mu \mathrm{m}$ Pall-Gelman capsule filters. Our target dilutions ( 7 dilutions, 1 bottle per dilution) per dilution assay were $95,85,75,65,55,35$, and $0 \%$ diluent (i.e. diluent: $<202 \mu \mathrm{m}$ size-fractionated 
seawater). Appropriate volumes of diluent were added to 21 polycarbonate incubation bottles. The $<202 \mu \mathrm{m}$ seawater was then added to bottles by dispensing $0.5 \mathrm{~m}$ collected seawater through silicon tubing that was equipped with a $202 \mu \mathrm{m}$ Nitex screen. The silicon tubing was kept submerged below the waterline in the bottles to reduce damage to microzooplankton. Bottles were placed on a plankton wheel $(\sim 0.5 \mathrm{rpm})$ and incubated in an outdoor incubator flushed continuously with seawater from Apalachicola Bay. Since there was no spatial variation in surface temperature at any sample time (see 'Results'), on each sampling date bottles were incubated at the same temperature. Incident irradiance was attenuated with neutral density screening to simulate the light energy from the collection site.

Samples were taken for chlorophyll $a$ and bacterioplankton immediately after preparation of dilution treatments and again after $24 \mathrm{~h}$. Samples for bacterioplankton and chlorophyll a were preserved, stored, and analyzed using the procedures previously mentioned.

Microzooplankton grazing calculations. Rates of growth and grazing mortality for chlorophyll $a$ and bacterioplankton were estimated with Model I linear regressions of apparent growth rate (AGR) versus actual dilution factor (ADF). The ADF for each bottle was calculated as:

$$
\mathrm{ADF}=\frac{T_{0} \operatorname{chl} a\left(X_{i}\right)}{T_{0} \operatorname{chl} a\left(X_{0}\right)}
$$

where $T_{0}$ chl a $\left(X_{i}\right)$ is the Time zero chlorophyll a concentration at target dilution factor $X_{i}$ and $T_{0}$ chl a $\left(X_{0}\right)$ is the Time zero chlorophyll a concentration of the $0 \%$ dilution treatment. The prey AGR $\left(\mathrm{d}^{-1}\right)$ in each incubation bottle was calculated as:

$$
\mathrm{AGR}=\frac{1}{t} \ln \left(\frac{P_{\mathrm{t}}}{P_{0}}\right)
$$

where $t$ is the duration of the incubation (d) and $P_{0}$ and $P_{\mathrm{t}}$ are the initial and final prey densities, respectively. The ordinal intercept of the regression is the rate of prey growth $\left(\mu, \mathrm{d}^{-1}\right)$ in the absence of grazing while the absolute value of the negative slope is grazing mortality $\left(g, \mathrm{~d}^{-1}\right)$.

In cases where the relationship between ADF and AGR was non-linear, piecewise linear regression (Redden et al. 2002) was used to estimate prey growth and grazing mortality. The dilution plot was decomposed into 2 regions. The region corresponding to relatively low ADF (i.e. high \% diluent) and statistically significant negative slope was used to estimate prey growth. In this region, AGR was regressed against ADF and the ordinal intercept was taken as the estimate of prey growth. The region corresponding to relatively high ADF (i.e. low \% diluent) and a slope not statistically significantly different from zero was used to estimate the mean AGR $\left(\mathrm{AGR}_{\text {mean }}\right)$. The grazing mortality for non-linear dilution plots was then estimated as:

$$
g=\mu-\mathrm{AGR}_{\text {mean }}
$$

The impact of microzooplankton grazing on phytoplankton was assessed by calculating the percentage of phytoplankton potential productivity ingested $\left(\% P_{\mathrm{i}}\right)$.

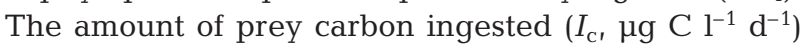
was calculated as:

$$
\begin{gathered}
\% P_{i}=\frac{\left[\left(P_{0} \mathrm{e}^{\mu t}-P_{0}\right)-\left(P_{0} \mathrm{e}^{(\mu-g) t}-P_{0}\right)\right]}{\left(P_{0} \mathrm{e}^{\mu t}-P_{0}\right)} \times 100 \\
I_{\mathrm{c}}=g C_{\mathrm{m}}
\end{gathered}
$$

where $t$ is $1 \mathrm{~d}$ and $C_{\mathrm{m}}$ is the mean prey carbon $\left(\mu \mathrm{g} \mathrm{C} \mathrm{l}^{-1}\right)$ in the $0 \%$ diluent treatment calculated as:

$$
C_{\mathrm{m}}=\frac{C_{0}\left(\mathrm{e}^{(\mu-g) t}-1\right)}{(\mu-g) t}
$$

where $C_{0}$ is the initial prey carbon $\left(\mu \mathrm{g} \mathrm{Cl}^{-1}\right)$ in the $0 \%$ diluent treatment.

Conversion factors. Phytoplankton carbon was estimated from measured chlorophyll $a$ and carbon:chlorophyll ratios determined for Apalachicola Bay (Putland \& Iverson in press). For bacterioplankton, $20 \mathrm{fg} \mathrm{C}$ cell $^{-1}$ was assumed (Ducklow 2000).

Statistical analyses. Non-linear regressions were used when a linear regression model did not adequately explain the relation between variables (for example, low $\mathrm{r}^{2}$, variances heteroscedastic). Relationships were considered statistically significant if the p-value was $<0.05$ (Sokal \& Rohlf 1995). Analysis of covariance (ANCOVA) tests were used to determine if statistically significant differences existed between years for relationships between variables. If no statistically significant difference was found, then data were pooled and a common regression equation was determined. Nonlinear relationships were analyzed by dividing the data into 2 components: (1) the increasing segment and (2) the decreasing segment. ANCOVA tests were performed on each segment.

\section{RESULTS}

\section{Surface salinity}

The areal extent of lower $(<20$ psu) salinity water was, on average, greater during summer 2003 (Fig. 2A) than during summer 2004 (Fig. 2B). On average, 100\% of the bay was $<20$ psu during summer 2003. In contrast, during summer 2004 about $50 \%$ of the bay was $<20$ psu. 


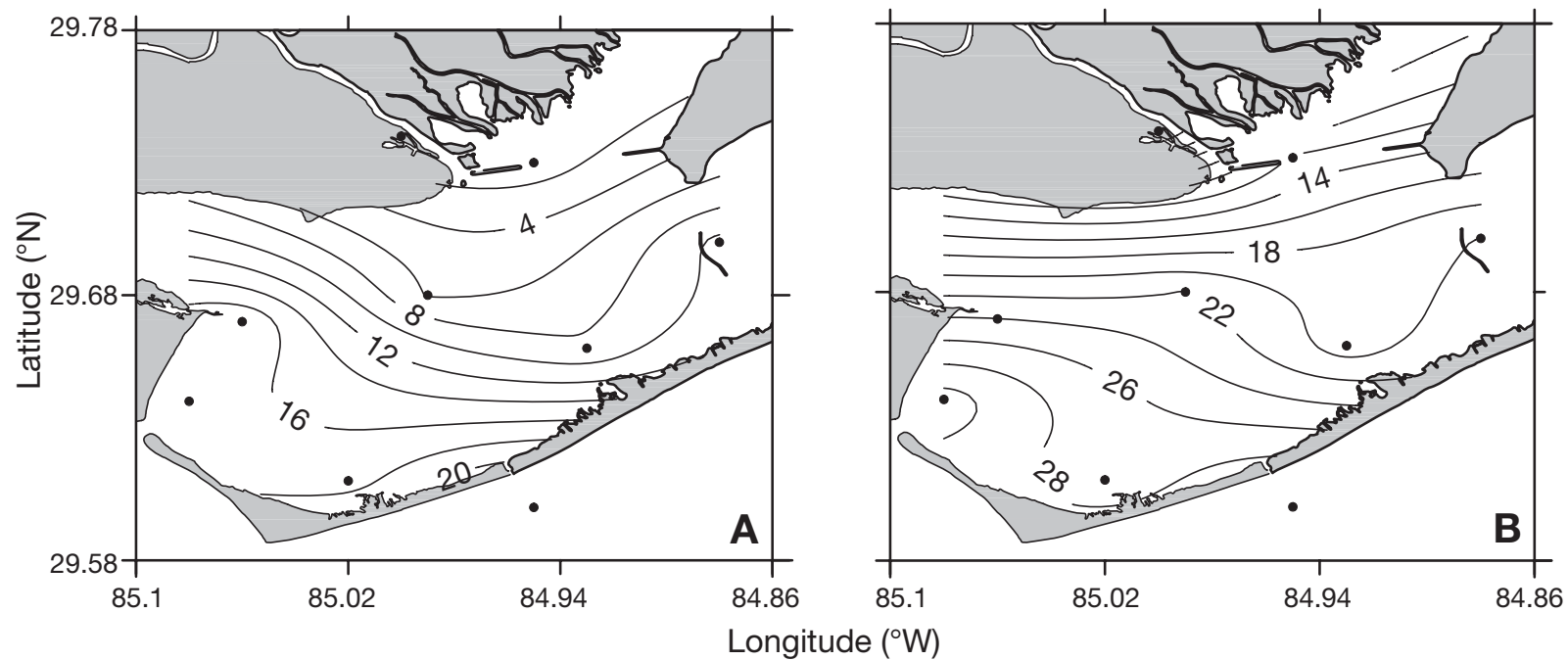

Fig. 2. Averaged surface salinity (psu) distribution in Apalachicola Bay during (A) summer 2003 and (B) summer 2004. (Data courtesy of Apalachicola National Estuarine Research Reserve)

\section{Temperature}

There was no relationship between surface temperature and salinity at any time that we sampled. Average surface temperature in the bay peaked between about May and October during both years. We defined temperatures above about $26^{\circ} \mathrm{C}$ as summer and those below $26^{\circ} \mathrm{C}$ as winter (Fig. 3).

\section{Total prey carbon}

During both years, total prey carbon peaked during summer (Fig. 4A). During summer, total prey carbon peaked in lower (10 to $20 \mathrm{psu}$ ) salinity water (Fig. 4B) and was primarily $(>50 \%$ ) composed of phytoplankton in waters with salinity below 32 psu (Fig. 4C).

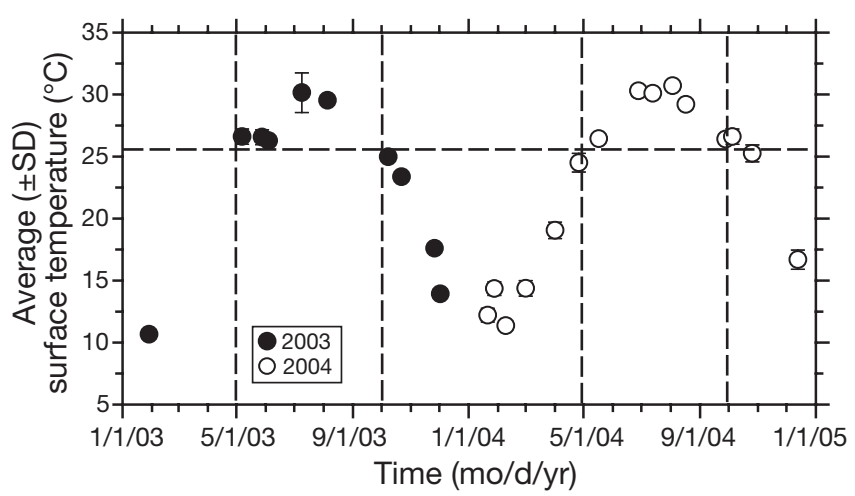

Fig. 3. Annual cycle of surface temperature during 2003 and 2004. Summer defined as temperatures above $\sim 26^{\circ} \mathrm{C}$ (horizontal dashed line), which typically corresponds to period between May and October (vertical dashed lines)
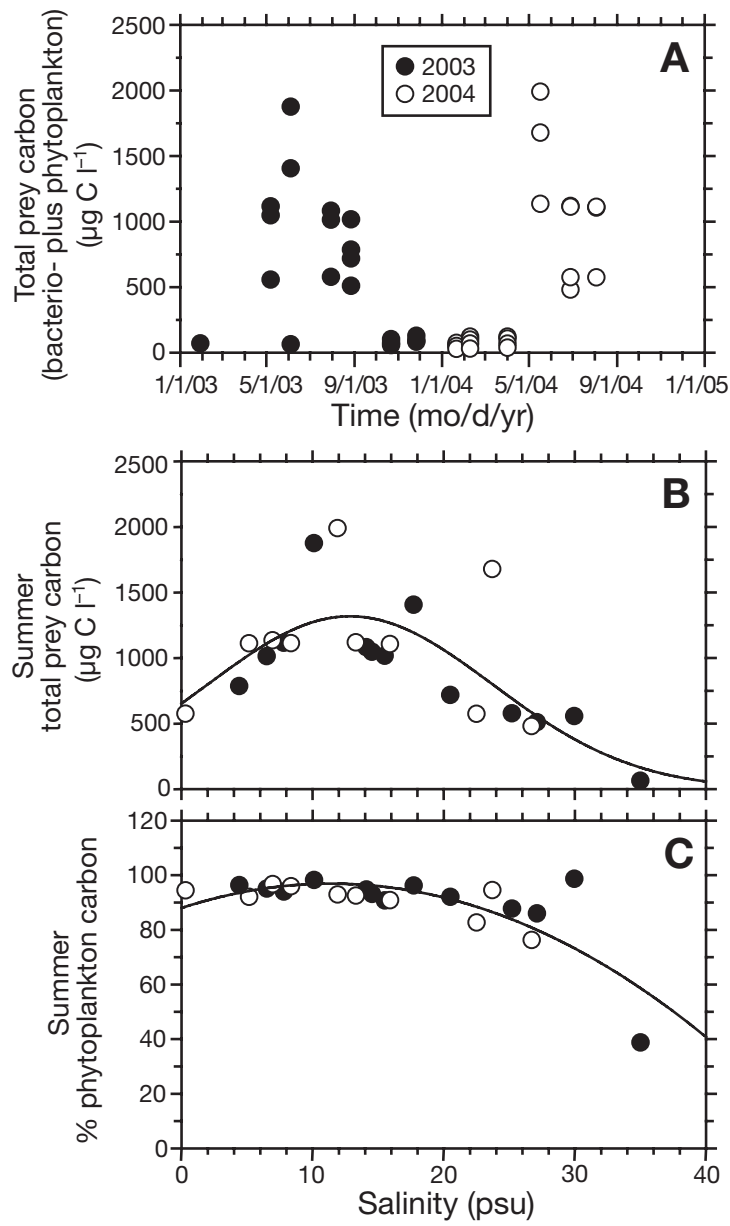

Fig. 4. (A) Annual cycle of total prey carbon. (B) Total prey carbon relative to sea surface salinity during summer. Regression: $y=1317 \mathrm{e}^{-0.5 \cdot((x-13) / 11)^{2}} \mathrm{r}^{2}=0.53, \mathrm{p}<0.01$. (C) Percent of total prey carbon composed of phytoplankton carbon relative to sea surface salinity during summer; other portion of carbon available is heterotrophic bacterioplankton carbon; regression: $y=88+2 x-0.1 x^{2}, r^{2}=0.59, p<0.01$ 


\section{Microzooplankton abundance}

The ciliate community was primarily $(70 \%)$ composed of ciliates $<20 \mu \mathrm{m}$ in size (Table 1). During 2003, ciliate abundance increased from an average $( \pm$ SD) of $12 \pm 9 \times 10^{3}$ cells $l^{-1}$ during winter to $26 \pm 17 \times 10^{3}$ cells during summer. In contrast, during 2004 ciliates did not show a seasonal pattern in abundance (Fig. 5) During 2004, ciliate abundance averaged $14 \pm 10 \times 10^{3}$ cells $\mathrm{l}^{-1}$ during winter and $13 \pm 13 \times 10^{3}$ cells during summer. There were no strong relationships between ciliate abundance and salinity during either summer.

We estimated dinoflagellate $(>20 \mu \mathrm{m})$ and heterotrophic flagellate (5 to $20 \mu \mathrm{m}$ ) abundances periodically
Table 1. Rates of phytoplankton growth $\left(\mu, \mathrm{d}^{-1}\right)$ and microzooplankton herbivory $\left(g, \mathrm{~d}^{-1}\right)$, coefficient of determination $\left(\mathrm{r}^{2}\right)$, ciliate abundance $\left(\mathrm{C}\right.$, cells $\times 10^{4} \mathrm{l}^{-1}$ : total and \% that were $<20 \mu \mathrm{m}$ in size), 5 to $20 \mu \mathrm{m}$ flagellate abundance ( $\mathrm{F}$, cells $\left.\times 10^{6} \mathrm{l}^{-1}\right)$ and $>20 \mu \mathrm{m}$ dinoflagellate abundance $\left(\mathrm{D}\right.$, cells $\left.\times 10^{4} \mathrm{l}^{-1}\right)$ at various surface salinities (psu) in Apalachicola Bay, Florida. PLR $=$ piecewise linear regression. All regressions were significant at $p<0.05$, except where noted as ns (not significant). (-) abundances not determined

\begin{tabular}{|c|c|c|c|c|c|c|c|c|}
\hline \multirow[t]{2}{*}{ Date } & \multirow[t]{2}{*}{ Salinity } & \multirow[t]{2}{*}{$\mu$} & \multirow[t]{2}{*}{$g$} & \multirow[t]{2}{*}{$r^{2}$} & \multicolumn{2}{|c|}{$-\mathrm{C}-$} & \multirow[t]{2}{*}{$\mathrm{F}$} & \multirow[t]{2}{*}{ D } \\
\hline & & & & & Total & $\%$ & & \\
\hline \multicolumn{9}{|l|}{ Winter } \\
\hline 29 Jan 03 & 6.70 & 0.52 & 0.39 & 0.98 & 1.0 & - & 1 & 0.6 \\
\hline 22 Oct 03 & 29.80 & 1.11 & 1.53 & 0.99 & 2.0 & 69 & - & - \\
\hline 22 Oct 03 & 19.90 & 1.21 & 1.32 & 0.99 & 0.9 & 80 & - & - \\
\hline 22 Oct 03 & 9.30 & 0.75 & 0.57 & 0.96 & 0.9 & 60 & - & - \\
\hline 26 Nov 03 & 31.25 & 0.91 & 0.78 & 0.98 & 0.8 & 53 & 0.5 & 1 \\
\hline 26 Nov 03 & 22.30 & 1.02 & 0.26 & 0.86 & 0.5 & 60 & 0.1 & 0.02 \\
\hline 26 Nov 03 & 12.70 & 0.95 & 0.90 & 0.94 & 3.4 & 80 & 0.5 & 2 \\
\hline 21 Jan 04 & 5.80 & 0.28 & 0.32 & 0.92 & 1.1 & - & - & - \\
\hline 21 Jan 04 & 14.60 & 0.46 & 0.51 & 0.98 & 0.6 & - & - & - \\
\hline 21 Jan 04 & 32.50 & 0.29 & 0.32 & 0.96 & 0.9 & - & 0.4 & 0.4 \\
\hline 21 Jan 04 & 1.70 & 0.17 & 0.00 & $0.03^{\mathrm{ns}}$ & 0.1 & - & - & - \\
\hline 09 Feb 04 & 18.60 & 0.77 & 0.14 & 0.90 & 1.0 & - & - & - \\
\hline 09 Feb 04 & 11.50 & 0.36 & 0.13 & 0.95 & 0.4 & - & - & - \\
\hline 09 Feb 04 & 5.00 & 0.27 & 0.07 & 0.65 & 0.2 & - & - & - \\
\hline 09 Feb 04 & 0.30 & 0.37 & 0.12 & 0.88 & 0.3 & - & - & - \\
\hline 01 Apr 04 & 28.25 & 0.40 & 0.63 & 0.93 & 2.1 & - & - & - \\
\hline 01 Apr 04 & 13.10 & 0.37 & 0.22 & 0.89 & 1.7 & - & - & - \\
\hline 01 Apr 04 & 8.30 & 0.40 & 0.13 & 0.80 & 1.9 & - & - & - \\
\hline 01 Apr 04 & 0.40 & 0.44 & 0.49 & 0.52 & 0.2 & - & - & - \\
\hline \multicolumn{9}{|l|}{ Summer } \\
\hline 07 May 03 & 29.95 & 1.64 & 1.32 & 0.95 & 3.4 & 69 & 4 & 2 \\
\hline 07 May 03 & 14.53 & 1.67 & 1.94 & PLR & 2.3 & 94 & 20 & 1 \\
\hline 07 May 03 & 7.80 & 1.52 & 1.50 & PLR & 1.0 & 33 & 2 & 0.02 \\
\hline 04 Jun 03 & 10.10 & 1.41 & 1.13 & PLR & 2.4 & 54 & 3 & 2 \\
\hline 04 Jun 03 & 17.70 & 1.92 & 1.95 & PLR & 2.4 & 77 & 2 & 0.06 \\
\hline 04 Jun 03 & 35.00 & 1.44 & 1.02 & 0.98 & 3.2 & 68 & 2 & 2 \\
\hline $30 \mathrm{Jul} 03$ & 6.50 & 0.81 & 0.95 & PLR & 1.4 & 53 & - & - \\
\hline 30 Jul 03 & 14.10 & 0.96 & 0.98 & 0.79 & 4.0 & 79 & - & - \\
\hline $30 \mathrm{Jul} 03$ & 25.20 & 0.94 & 1.20 & 0.84 & 1.5 & 73 & - & - \\
\hline 27 Aug 03 & 4.40 & 1.45 & 1.25 & PLR & 2.0 & 96 & - & - \\
\hline 27 Aug 03 & 15.50 & 1.31 & 1.18 & PLR & 3.7 & 84 & - & - \\
\hline 27 Aug 03 & 20.50 & 1.22 & 1.30 & 0.98 & 2.6 & 83 & - & - \\
\hline 27 Aug 03 & 27.10 & 0.36 & 0.59 & PLR & 4.8 & 47 & - & - \\
\hline 17 May 04 & 6.95 & 1.30 & 1.01 & PLR & 0.8 & - & 1 & 2 \\
\hline 17 May 04 & 11.90 & 0.96 & 0.67 & PLR & 1.0 & - & - & - \\
\hline 17 May 04 & 23.70 & 0.60 & 0.38 & PLR & 1.5 & - & 1 & 0.4 \\
\hline 28 Jun 04 & 26.70 & 0.19 & 0.33 & 0.73 & 3.7 & - & - & - \\
\hline 28 Jun 04 & 13.30 & 0.28 & 0.47 & PLR & 3.1 & - & - & - \\
\hline 28 Jun 04 & 8.35 & 0.28 & 0.36 & PLR & 2.1 & - & - & - \\
\hline 28 Jun 04 & 0.30 & 0.20 & 0.41 & PLR & 0.4 & - & - & - \\
\hline 03 Aug 04 & 22.50 & 0.08 & 0.25 & PLR & 2.0 & - & - & - \\
\hline 03 Aug 04 & 15.90 & 0.21 & 0.34 & PLR & 1.2 & - & - & - \\
\hline 03 Aug 04 & 5.15 & 0.42 & 0.49 & PLR & 2.7 & - & - & - \\
\hline
\end{tabular}

(Table 1). Mean abundances were higher in summer than during winter. Mean heterotrophic flagellate (5 to $20 \mu \mathrm{m}$ ) abundances were $4 \times 10^{6}{\text { cells } \mathrm{l}^{-1}}^{-1}$ and $5 \times 10^{5}$ cells $1^{-1}$ during summer and winter, respectively. Mean dinoflagellate $(>20 \mu \mathrm{m})$ abundances were $1 \times 10^{4}$ cells $\mathrm{l}^{-1}$ and $8 \times 10^{3}$ cells $\mathrm{l}^{-1}$ during summer and winter, respectively.

Abundance of dinoflagellates $>20 \mu \mathrm{m}$ in size was not statistically significantly related to herbivory. In contrast, abundances of 5 to $20 \mu \mathrm{m}$ heterotrophic flagellates and total ciliates were statistically significantly related to herbivory (Fig. 6). Abundances were transformed to a logarithmic scale so that variances were homoscedastic.

\section{Microzooplankton grazing}

The dilution method assumes that prey growth is exponential and constant across the dilution gradient. We added nitrogen to incubation bottles to prevent nitrogen limitation. None of the dilution plots assessing herbivory (Table 1) or bacterivory had positive slopes. This suggests that phytoplankton and bacterioplankton were not nutrient limited within our dilution assays.

Non-linear plots of phytoplankton AGR versus ADF only occurred during summer and were frequent $(74 \%$ of summer assays had non-linear plots) (Table 1). The coefficient of determination for linear regressions ranged from 0.03 to 0.99 and averaged $0.86( \pm 0.21$ $\mathrm{SD})$.

Non-linear plots of bacterial AGR versus ADF occurred primarily during summer and were infrequent $(22 \%$ of assays had non-linear plots). The coefficient of determination for linear regressions ranged from 0.25 to 0.98 and averaged $0.67( \pm 0.20 \mathrm{SD})$. 


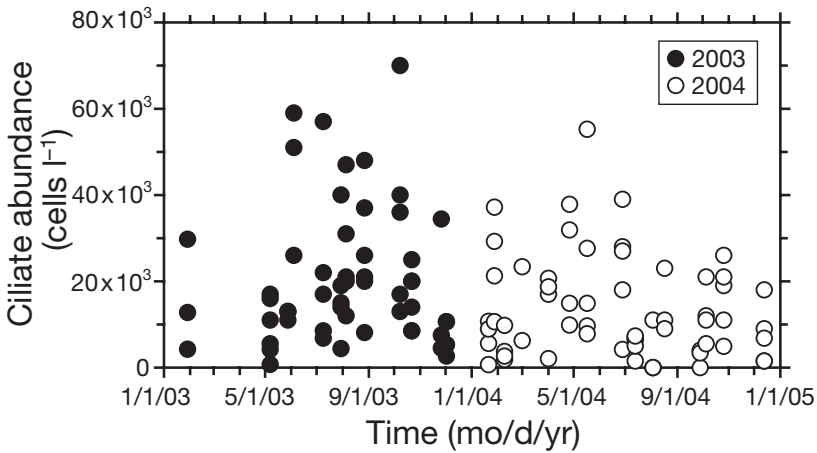

Fig. 5. Ciliate abundance during 2003 and 2004

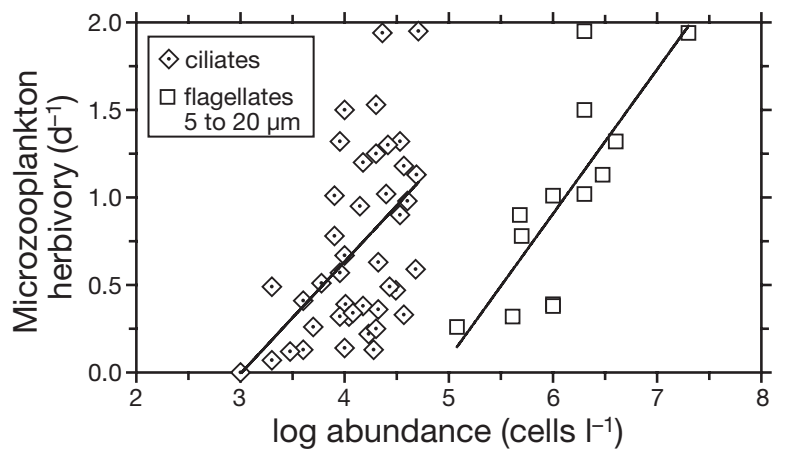

Fig. 6. Microzooplankton herbivory relative to log heterotrophic flagellate (5 to $20 \mu \mathrm{m}$ ) and ciliate abundance. Correlation for ciliates: $r=0.50, p<0.01$; correlation for flagellates:

$$
\mathrm{r}=0.79, \mathrm{p}<0.05
$$

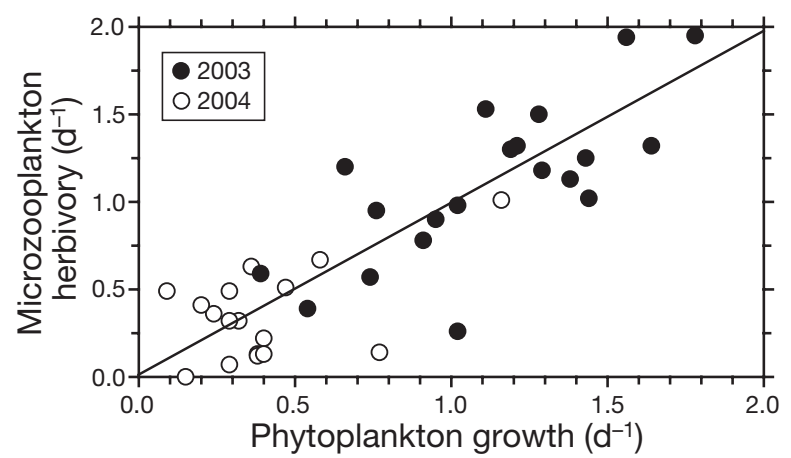

Fig. 7. Coupling of microzooplankton herbivory and phytoplankton growth. Diagonal line denotes 1:1 coupling between growth and grazing. Correlation: $r=0.88, p<0.01$

Phytoplankton growth and herbivory were statistically significantly related and there were no statistically significant differences between years or seasons for the relation (Fig. 7). The $\% P_{\mathrm{i}}$ tended to be greatest during the summer (Fig. 8A) and was not related to salinity (Fig. 8B).

Microzooplankton herbivory was greatest during summer (Fig. 9A) and was not related to salinity during
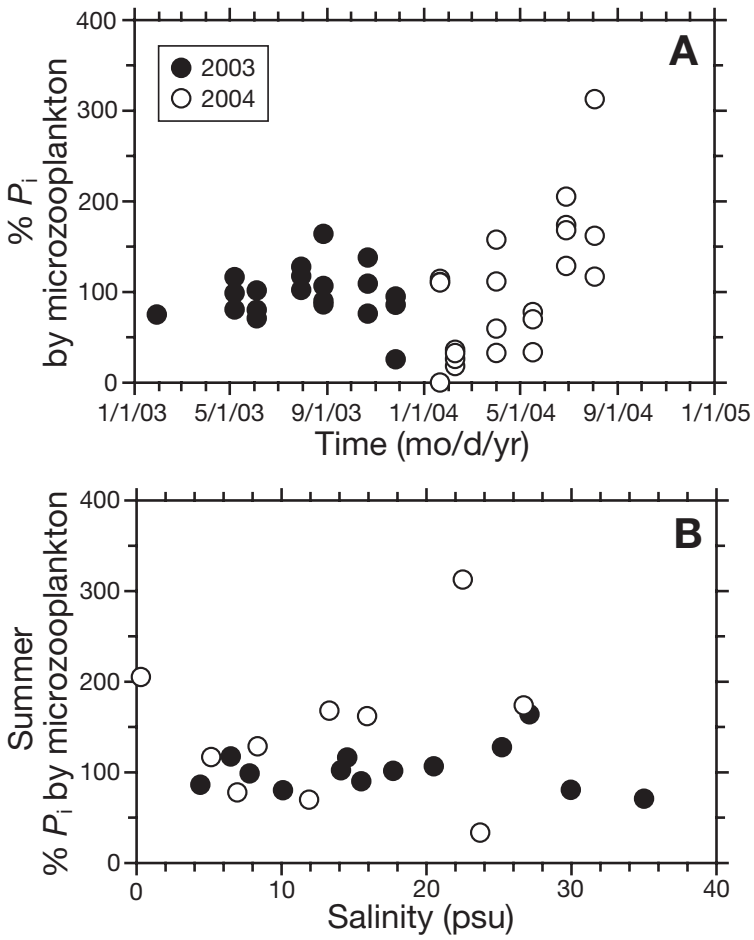

Fig. 8. (A) Annual cycle of phytoplankton potential productivity ingested $\left(\% P_{\mathrm{i}}\right)$ by microzooplankton. (B) The $\% P_{\mathrm{i}}$ relative to sea surface salinity during summer
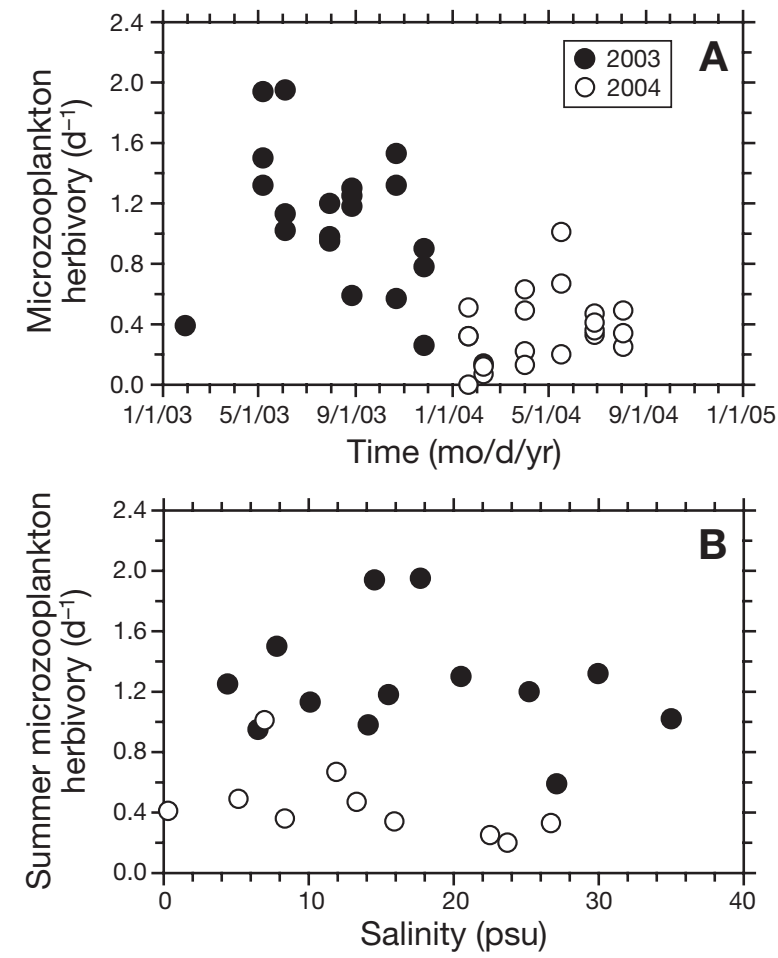

Fig. 9. (A) Annual cycle of microzooplankton herbivory. (B) Microzooplankton herbivory relative to sea surface salinity during summer 

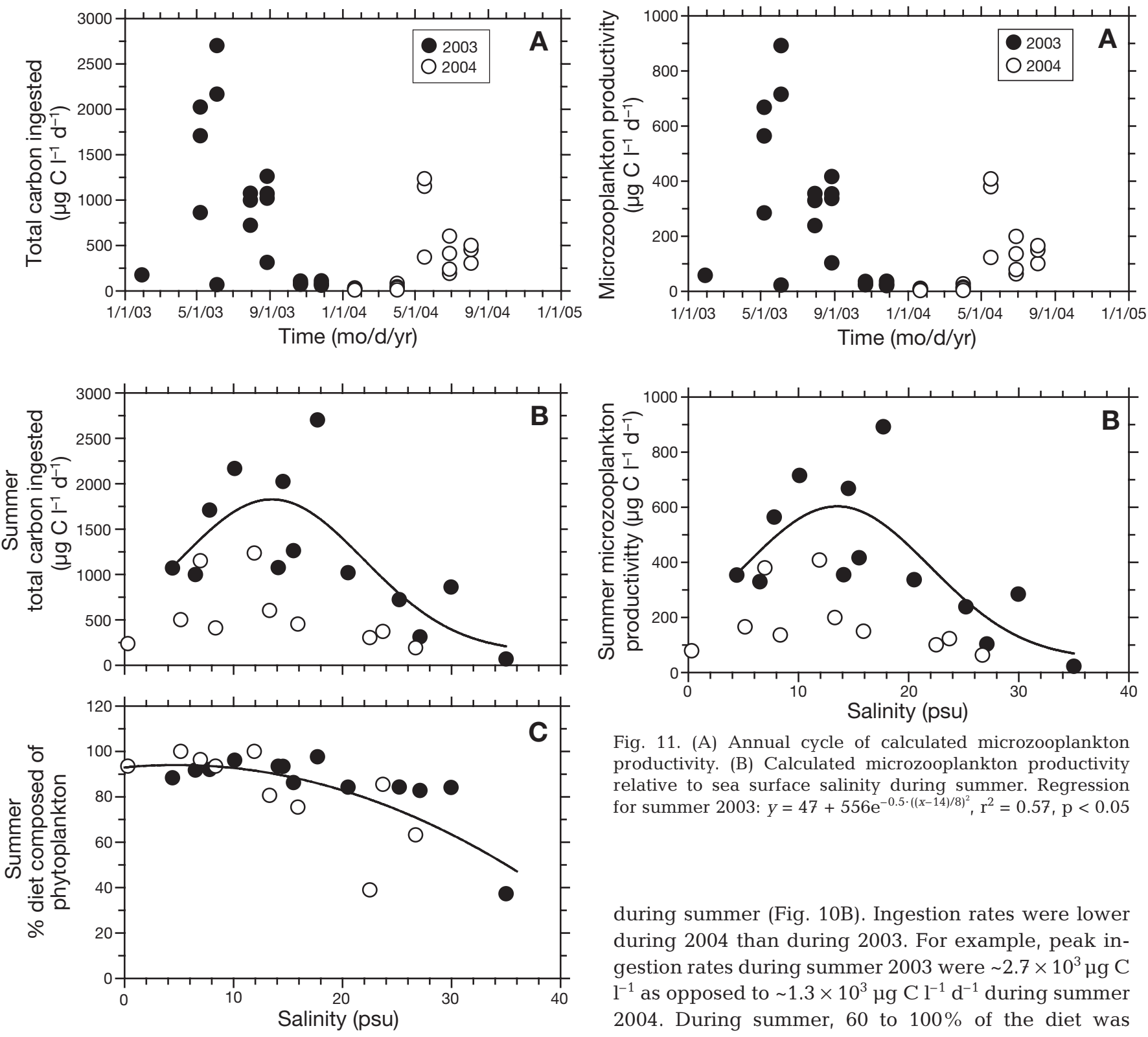

Fig. 11. (A) Annual cycle of calculated microzooplankton productivity. (B) Calculated microzooplankton productivity relative to sea surface salinity during summer. Regression for summer 2003: $y=47+556 \mathrm{e}^{-0.5 \cdot((x-14) / 8)^{2}}, \mathrm{r}^{2}=0.57, \mathrm{p}<0.05$

Fig. 10. (A) Annual cycle of total carbon ingested. (B) Total carbon ingested relative to sea surface salinity during summer. Regression for summer 2003: $y=143+1684 \mathrm{e}^{-0.5 \cdot((x-14) / 8)^{2}}$ $\mathrm{r}^{2}=0.57, \mathrm{p}<0.05$. (C) Percent total prey carbon ingested composed of phytoplankton carbon relative to sea surface salinity during summer 2003 and 2004; other portion of ingested ration is derived from heterotrophic bacterioplankton carbon; regression: $y=93+0.5 x-0.05 x^{2}, r^{2}=0.49, p<0.01$

summer (Fig. 9B). Microzooplankton herbivory was lower in 2004 than in 2003. Average $( \pm \mathrm{SD})$ microzooplankton herbivory was $1.3 \pm 0.4 \mathrm{~d}^{-1}$ during summer 2003 and $0.5 \pm 0.2 \mathrm{~d}^{-1}$ during summer 2004 .

Total prey carbon ingested was greatest during summer (Fig. 10A) and in lower (8 to 18 psu) salinity waters

during summer (Fig. 10B). Ingestion rates were lower during 2004 than during 2003. For example, peak ingestion rates during summer 2003 were $\sim 2.7 \times 10^{3} \mu \mathrm{g} \mathrm{C}$ $\mathrm{l}^{-1}$ as opposed to $\sim 1.3 \times 10^{3} \mu \mathrm{g} \mathrm{Cl}^{-1} \mathrm{~d}^{-1}$ during summer 2004. During summer, 60 to $100 \%$ of the diet was composed of phytoplankton at salinities below 26 psu (Fig. 10C)

Microzooplankton productivity was calculated with total ingestion rate and assuming a gross growth efficiency (GGE) of 33\% (Straile 1997). Microzooplankton productivity was therefore greater during summer (Fig. 11A) and in lower salinity waters during summer (Fig. 11B). Compared to 2003, microzooplankton productivity was lower during 2004. Peak microzooplankton productivity was about $9.0 \times 10^{2} \mu \mathrm{g} \mathrm{C}^{-1} \mathrm{~d}^{-1}$ during summer 2003 as opposed to about $4.0 \times 10^{2} \mu \mathrm{g} \mathrm{Cl}^{-1} \mathrm{~d}^{-1}$ during summer 2004. Salinity explained most of the variation $(30 \%)$ in microzooplankton productivity during summer 2003, while temperature explained most of the variation $(49 \%)$ in microzooplankton productivity during summer 2004. 


\section{DISCUSSION}

\section{Estuarine planktonic food web structure}

$$
\text { Phytoplankton - zooplankton }
$$

The classical food chain (diatoms-copepods-fishes) is typically used to describe the transfer of phytoplankton productivity to higher trophic levels in productive marine waters (Riegman et al. 1993, Legendre \& Rassoulzadegan 1995). This planktonic food web model describes conditions in productive waters such as upwelling on continental margins and spring blooms in temperate waters and may be appropriate for estuaries where the phytoplankton community is composed primarily of large cells (Ning et al. 2000). However, in Apalachicola Bay and other estuaries where phytoplankton $<20 \mu \mathrm{m}$ in size, not large diatoms, are the dominant component of the phytoplankton community (Putland \& Iverson in press), microzooplankton ingest most phytoplankton productivity (Gifford 1988, Juhl \& Murrell 2005).

The classical diatom-copepod food chain is not an accurate depiction of energy flow through the planktonic food web in Apalachicola Bay. First, during summer when primary productivity peaks (Mortazavi 1998), the dominant component of the phytoplankton community is $<5 \mu \mathrm{m}$ in size (Putland \& Iverson in press) and therefore relatively inaccessible to adult Acartia tonsa (Berggreen et al. 1988), the main numerical constituent of the mesozooplankton community in the bay (Edmiston 1979). Second, microzooplankton, on average, ingested 10 times more phytoplankton productivity (Fig. 8) than A. tonsa (Putland \& Iverson 2007). The fact that the seasonal peak of the percent of phytoplankton productivity ingested by microzooplankton followed the seasonal peak of phytoplankton biomass (Putland \& Iverson in press) also suggests that microzooplankton are the main planktonic herbivores in the bay.

Fast growth rates, an ability to ingest a wide size range of phytoplankton (Tillmann 2004), and high abundance (Gifford \& Caron 2000) are some of the main reasons cited to explain why microzooplankton are the main herbivores in some systems. In Apalachicola Bay, microzooplankton abundance was comparable to that found in other estuaries. For example, the range of abundances of ciliates in Apalachicola Bay (Table 1) was similar to that reported in other estuaries (Gifford \& Dagg 1988, Liu et al. 2005). Total abundances of flagellates and ciliates were statistically significantly related to herbivory (Fig. 6). Although total ciliates included mixotrophic and heterotrophic cells, the correlations suggest that both flagellates and ciliates were important constituents of the microherbivore community.
Bacterioplankton and phytoplankton are the main prey items of microzooplankton. Analyses by Landry \& Calbet (2004) indicate that microzooplankton are primarily supported by phytoplankton in marine waters. Chanton \& Lewis (2002) found that secondary producers in Apalachicola Bay are mainly supported by estuarine primary productivity. The present study supports the analyses of Chanton \& Lewis (2002), and Landry \& Calbet (2004). Phytoplankton carbon was the main component of carbon ingested by microzooplankton during the summer productive period (Fig.10C).

Microbial food web

A consensus is emerging that autochthonous algal production fuels estuarine food webs. Based upon the present analysis and previous studies, in estuarine planktonic food webs, mass and energy flows mainly from phytoplankton to microzooplankton to higher trophic level organisms such as copepods, first-feeding larvae, and oysters. Therefore, a microbial food web, emphasizing the importance of microzooplankton, as opposed to copepods, as primary herbivores and prey to higher trophic levels, is a more accurate depiction of energy and mass flow through estuarine planktonic food webs than a classical food chain. Unlike microbial food webs in oceanic waters, microbial food webs in estuarine waters should support higher trophic level productivity because (1) phytoplankton productivity is higher in estuarine than in oceanic waters (McLusky \& Elliot 2004), and (2) there are fewer trophic transfers between phytoplankton and higher trophic levels than in oceanic waters because copepods, larval shellfish, larval fishes, and oysters that occur in estuaries directly ingest microzooplankton (see 'Introduction' for references).

\section{Management implications}

There were striking differences in river discharge during summer 2003 and 2004 (Putland 2005). Associated with the lower river discharge of 2004, were lower nutrient concentrations at a particular salinity (Putland 2005). We suspect that these lower nutrient concentrations led to the lower phytoplankton growth rates (Putland 2005), rates of grazing (Fig. 9B), total ingestion (Fig. 10B), and microzooplankton productivity (Fig. 11B) observed at a particular salinity during 2004 than during 2003.

Nutrient concentrations, particularly nitrogen, are inversely related to salinity in Apalachicola Bay (Mortazavi 1998, Putland 2005). It is the relationship between parameters, such as productivity, and salinity/ 
nutrients together with the geographical extent over which the river plume extends that determines the overall effect of a reduction in river discharge. During the high river discharge of summer 2003 (Fig. 2A), lowto mid-salinity water $(<20 \mathrm{psu})$ extended outward to the barrier islands. In contrast, during the low river discharge of summer 2004 (Fig. 2B), low- to mid-salinity water $(<20 \mathrm{psu})$ extended from the mouth of the river to the middle of the bay. Results from this study show that during summer, total ingestion rate (Fig. 10B) and microzooplankton productivity (Fig. 11B) tend to be relatively low in higher (i.e. $>20 \mathrm{psu}$ ) salinity (lower nutrient) water. Therefore, based upon our study, summertime reductions in river discharge can be expected to reduce rates of grazing and ingestion and microzooplankton productivity at a particular salinity, as well as increase the areal extent of higher salinity (lower nutrient) water where ingestion and productivity of microzooplankton are relatively low. Because microzooplankton are key constituents of the estuarine food web in Apalachicola Bay, we predict that upstream water diversion will reduce higher trophic level productivity, in part because of reduced microzooplankton productivity.

Acknowledgements. This research was conducted under a Graduate Research Fellowship award to J.N.P. from the Estuarine Reserves Division, Office of Ocean and Coastal Resource Management, National Ocean Service, National Oceanic and Atmospheric Administration and SRAD funds from the Department of Oceanography, Florida State University to R.L.I. The authors thank the Department of Statistics, Florida State University, for providing statistical consultation, the Department of Biology, Florida State University for use of the epifluorescence microscope, L. Edmiston at the Apalachicola Bay National Research Reserve for providing assistance with sampling, and G. Lewis, N. Marcus, and anonymous reviewers for their constructive comments. This paper is part of a dissertation submitted to the Department of Oceanography, FSU, by J.N.P. in partial fulfillment of a PhD degree. Contribution No. 1106 of the Florida State University Marine Laboratory.

\section{LITERATURE CITED}

Berggreen U, Hansen B, Kiørboe T (1988) Food size spectra, ingestion and growth of the copepod Acartia tonsa during development: implications for determination of copepod production. Mar Biol 99:341-352

Calbet A, Landry MR (2004) Phytoplankton growth, microzooplankton grazing, and carbon cycling in marine systems. Limnol Oceanogr 49:51-57

Chanton J, Lewis FG (2002) Examination of coupling between primary and secondary production in a river-dominated estuary: Apalachicola Bay, Florida, USA Limnol Oceanogr 47:683-697

Ducklow HW (2000) Bacterial production and biomass in the oceans. In: Kirchman DL (ed) Microbial ecology of the oceans. Wiley-Liss, New York, p 85-113
Dupuy C, Le Gall S, Hartmann HJ, Breret M (1999) Retention of ciliates and flagellates by the oyster Crassostrea gigas in French Atlantic coastal ponds: protists as a trophic link between bacterioplankton and benthic suspension-feeders. Mar Ecol Prog Ser 177:165-175

Edmiston HL (1979) The zooplankton of the Apalachicola Bay system. MS thesis, Florida State University, Tallahassee

Estabrook RH (1973) Phytoplankton ecology and hydrography of Apalachicola Bay. MS thesis, Florida State University, Tallahassee, FL

Fukami K, Watanabe A, Fujita S, Yamaoka K, Nishijima T (1999) Predation on naked protozoan microzooplankton by fish larvae. Mar Ecol Prog Ser 185:285-291

Fulmer JM (1997) Nutrient enrichment and nutrient input to Apalachicola Bay, Florida. MS thesis, Florida State University, Tallahassee

Gifford DJ (1988) Impact of grazing by microzooplankton in the northwest arm of Halifax Harbor, Nova Scotia. Mar Ecol Prog Ser 47:249-258

Gifford DJ, Caron DA (2000) Sampling, preservation, enumeration and biomass of marine protozooplankton. In: Harris RP, Wiebe PH, Lenz J, Skjoldal HR, Huntley M (eds) ICES zooplankton methodology manual, Academic Press, San Diego, p 193-221

Gifford DJ, Dagg M (1988) Feeding of the estuarine copepod Acartia tonsa Dana: carnivory vs. herbivory in natural microplankton assemblages. Bull Mar Sci 43:458-468

Hobbie JE, Daley RJ, Jasper S (1977) Use of Nuclepore filters for counting bacteria by fluorescence microscopy. Appl Environ Microbiol 33:1225-1228

Hobro R, Willen E (1977) Phytoplankton countings. Intercalibration results and recommendations for routine work. Int Rev Hydrobiol 62:805-811

Juhl AR, Murrell MC (2005) Interactions between nutrients, phytoplankton growth, and microzooplankton grazing in a Gulf of Mexico estuary. Aquat Microb Ecol 38:147-156

Landry MR, Calbet A (2004) Microzooplankton production in the oceans. ICES J Mar Sci 61:501-507

Landry MR, Hassett RP (1982) Estimating the grazing impact of marine micro-zooplankton. Mar Biol 67:283-288

Legendre L, Rassoulzadegan F (1995) Plankton and nutrient dynamics in marine waters. Ophelia 41:153-172

Liu HB, Dagg M, Wu CJ, Chiang KP (2005) Mesozooplankton consumption of microplankton in the Mississippi River plume, with special emphasis on planktonic ciliates. Mar Ecol Prog Ser 286:133-144

Livingston RL (1984) The ecology of the Apalachicola Bay system: an estuarine profile. US Fish Wildl Serv FWS/OBS $82 / 05$

Livingston RL, Niu X, Lewis FG, Woodsum GC (1997) Freshwater input to a gulf estuary: long term control of trophic organization. Ecol Appl 7:277-299

McLusky DS, Elliot M (eds) (2004) The estuarine ecosystem. Ecology, threats, and management. Oxford University Press, New York

Mortazavi B (1998) Primary productivity and nitrogen cycling in Apalachicola Bay, FL, USA. PhD thesis, Florida State University, Tallahassee

Nagano N, Decamp O (2004) Ingestion of a ciliated protozoa by first-feeding larval stage of Pacific white shrimp, Litopenaeus vannamei (Boone). Aquac Res 35:516-518

Ning X, Cloern JE, Cole BE (2000) Spatial and temporal variability of picocyanobacteria Synechococcus sp. in San Francisco Bay. Limnol Oceanogr 45:695-702

Putland JN (2005) Ecology of phytoplankton, Acartia tonsa, and microzooplankton in Apalachicola Bay, Florida. PhD dissertation, Florida State University, Tallahassee 
Putland JN, Iverson RL (2007) Ecology of Acartia tonsa in Apalachicola Bay, Florida and implications of river water diversion. Mar Ecol Prog Ser 340:173-187

Putland JN, Iverson RL (in press) Phytoplankton biomass in a subtropical estuary: distribution, size composition, and carbon:chlorophyll ratios. Estuar Coast 30(5)

Redden AM, Sanderson BG, Rissik D (2002) Extending the analysis of the dilution method to obtain the phytoplankton concentration at which microzooplankton grazing becomes saturated. Mar Ecol Prog Ser 226:27-33

Riegman R, Kuipers BR, Noordeloos AAM, Witte HJ (1993) Size-differential control of phytoplankton and the structure of plankton communities. Neth J Sea Res 31:255-265

Rollwagen-Bollens GC, Penry DL (2003) Feeding dynamics of Acartia spp. copepods in a large, temperate estuary (San Francisco Bay, CA). Mar Ecol Prog Ser 257:139-158

Sherr B, Caron DA, Sherr E (1993) Staining of heterotrophic

Editorial responsibility: Howard Browman (Associate Editor-in-Chief), Storebø, Norway protists for visualization via epifluorescence microscopy. In: Kemp PF, Sherr BF, Sherr EB, Cole JJ (eds) Handbook of methods in aquatic microbial ecology. Lewis Publishers, Boca Raton, FL, p 213-227

Sokal RR, Rohlf FJ (1995) Biometry. The principles and practice of statistics in biological research, 3rd edn. WH Freeman \& Co, New York

Straile D (1997) Gross growth efficiencies of protozoan and metazoan zooplankton and their dependence on food concentration, predator-prey weight ratio, and taxonomic group. Limnol Oceanogr 42:1375-1385

Tillmann U (2004) Interactions between planktonic microalgae and protozoan grazers. J Eukaryot Microbiol 51: 156-168

Welschmeyer N (1994) Fluorometric analysis of chlorophyll a in the presence of chlorophyll $b$ and phaeopigments. Limnol Oceanogr 39:1985-1992

Submitted: February 2, 2006; Accepted: December 11, 2006 Proofs received from author(s): August 3, 2007 